\title{
A critical overview of progress in studies of migration of dragonflies (Odonata: Anisoptera), with emphasis on North America
}

\author{
Michael L. May
}

Received: 8 May 2012/Accepted: 1 November 2012/Published online: 20 November 2012

(C) The Author(s) 2012. This article is published with open access at Springerlink.com

\begin{abstract}
Migration by Odonata has been recorded sporadically for several centuries, but only recently have new technologies and a new wave of interest in these ancient insects sparked a concerted effort to understand the extent, behavioral mechanisms, adaptive significance, and ecological consequences of this phenomenon. Here I review our current knowledge of these sometimes spectacular flights, focusing on the few species in North America that are known to migrate more or less annually. One of these, the Common Green Darner, Anax junius, has been shown to traverse hundreds to thousands of kilometers from north to south during fall migration. Pantala flavescens (Wandering Glider) is plausibly inferred to make an overseas flight from India to East Africa with the Northeast Monsoon, although its migrations in North America are less well understood. Large scale movements of these and other species raises questions about population connectivity, ecosystem impacts, the nature and evolution of cues that initiate migration, and effects of climate change on these phenomena.
\end{abstract}

Keywords Insect migration - Anax junius $\cdot$ Pantala flavescens . Climate - Wetland ecology

\section{Introduction}

In North America, public perception of insect migration is mostly confined to Monarch butterflies, which famously and spectacularly migrate to and overwinter along the coast

M. L. May $(\bowtie)$

Department of Entomology, Rutgers University,

New Brunswick, NJ 08901, USA

e-mail: may@aesop.rutgers.edu of California or, by the millions, in a few forests of Mexico's Sierra Madre. Preservation of their overwintering sites and their food plants has become a major focus of conservation efforts (Oberhauser et al. 2008; Borders and Shepherd 2011). In fact, many species of insects migrate, some, like Monarchs, over thousands of kilometers. Because a few of these, including the so-called plague locusts of Africa, South Asia, and Australia, as well as armyworm and other moths on several continents, are serious crop pests, their sudden appearances in vast numbers have been studied for well over a century, as summarized and synthesized by Dingle (1996, 2006), Kennedy (1961, 1985), Southwood (1962), Taylor (1974), and Williams (1958), among others.

Less well known, perhaps because Odonata are not of great direct economic importance, is that some dragonflies also are long-distance migrants. Nonetheless, they rank among the "charismatic megafauna" of insects, and their occasional mass migrations may attract widespread public attention (e.g., Mitchell and Lasswell 2005; Highfield 2006). The earliest record of dragonfly migrations in North America may have been Hagen's (1861) brief mention of apparent migrations in Tramea lacerata [Black Saddlebags; common names from Paulson and Dunkle 2012 (North America) and Dijkstra and Lewington 2006 (Europe, Africa)]. Calvert (1893) cited reports of annual migrations in a number of species, as well as records in Europe dating to 1494. Movements along the East Coast and upper Midwest of the United States, were recorded and mapped by Shannon in 1916. Thereafter, however, only scattered anecdotal descriptions were added to the literature until the work of Corbet, Trottier, and their associates in the late 1960s and 1970s (see below).

In general, migrant Odonata are not currently under threat from human activity, largely because they are 
adapted to more or less unstable habitats, including manmade ones, they are extremely mobile, and show some evidence of adaptation to climate warming (Ott 2001; Hickling et al. 2005). It is possible, of course, that phenological responses to climate change (Hassal et al. 2007; Dingmanse and Kalkman 2008) might affect the occurrence and timing of migration (Matthews 2004, 2007a, b). Aside from any direct threats, however, migratory Odonata are of potential interest to conservationists because (1) they may have an important influence on the ecology of many wetlands, including effects on biodiversity as a consequence of the periodic influx of important predators of invertebrates, small fish, and larval amphibians and of prey of larger, insectivorous fish; (2) species that include both migrant and non-migrant individuals might be limited in their ability to adapt to local conditions by genetic swamping by migrants (Matthews 2007c); (3) migrant adults may, in certain circumstances, provide a significant food source for co-migrant birds (Jaramillo 1993; Nicoletti 1996), while local high densities of adults are known to be major mortality factors for some prey insects (Sang and Teder 2011); (4) they could herald changes, positive or negative, in wetland health (Matthews 2004, 2007a, b); (5) migrant dragonflies have the potential to attract public attention and interest to insects as they contribute to in regional and global biodiversity and connectivity; and (6) many aspects of their migratory behavior remain poorly known (Mazzacano 2011).

Even now, answers to questions about the identity of regularly migrating species, the frequency of migration, and sources, routes and destinations of migrants are only beginning to be satisfactorily documented. These and many other related questions deserve a great deal more attention from biologists interested in insect movements, from amateur and professional odonatologists, and from the general public. Although migrations can be spectacular, flights are often diffuse and unpredictable, and their study could be substantially advanced by widespread observation that is regular when possible and opportunistic when necessary. The field is still one to which anyone interested in this fascinating and sometimes astonishing phenomenon can make a real contribution if trained to distinguish a few species of dragonflies on the wing and to keep careful records of their observations. Participation in such studies could encourage awareness of insect biodiversity and the role of insects in ecosystems over a broad geographic range (Matthews 2007a; Mazzacano 2011).

\section{Which dragonflies migrate?}

It is not always easy to identify migrant dragonflies as such. Most obvious (e.g., Osburn 1916; Borror 1953; Cook 1991;
Daigle 1991; Glotzhober 1991) are those flying together in large swarms that move in a common direction for sustained periods. Based on credible reports of swarms numbering in the millions (Russell et al. 1998), such events must be an important part of migration. Nevertheless, many migrants may travel as scattered individuals or small groups that attract much less notice (Nicoletti 1996; Sprandel 2001). These migrants sometimes can be recognized in the fall as individuals in sustained, directional flight, often along coastlines or other landmarks (Shannon 1935, 1916; Bagg 1958; Dumont 1977; Sprandel 2001) or aggregated in late summer/fall at southward-directed points of land, like Cape May, New Jersey, or Point Pelee, Ontario (Root 1912; Nisbet 1960; Corbet 1984), although non-migrant feeding aggregations may occur during the same time period (e.g., Wright 1945; pers. obs. 1998-2011).

The adaptive function of migration is to move individuals and populations from an initially suitable habitat that deteriorates with time to an alternative and currently more favorable habitat. Practical considerations, however, largely necessitate use of behavioral definitions dependent on observation of directional flight and reduced responsiveness to stimuli that normally encourage localization (e.g., food, suitable sites for reproduction; Kennedy 1985; Dingle 1996, 2006). Even these criteria may be difficult to apply, so it remains unclear how many North American species are either regular or irruptive migrants. This question was discussed by Russell et al. (1998), who listed 18 migrant species reported reliably in the literature. To these, Sympetrum vicinum (Autumn Meadowhawk) might be added (Corbet and Eda 1969; Catling and Brownell 1998), although these may instead be making seasonal refuge flights rather than long-distance latitudinal migrations (Corbet 1999). In North America, Anax junius, Tramea lacerata (Black Saddlebags), Pantala flavescens (Wandering Glider), P. hymenea (Spot-winged Glider) and Sympetrum corruptum (Variegated Meadowhawk) are the species in which long-distance migration is best documented. Genera commonly cited as migrants include members of Pantala, Tramea, Sympetrum, Libellula (all Libellulidae), Anax, Aeshna, and Epiaeschna (Aeshnidae); all except the North American endemic, E. heros, include known migrants elsewhere (Dumont and Hinnekint 1973; Dumont 1977; Corbet 1999; Dyatlova and Kalkman 2008; Haritonov and Popova 2011).

Annual migration presumably indicates that migration is a regular, adaptive part of the life cycle, whereas occasional irruptions may have different, or perhaps no, adaptive significance. The latter has been suggested by Dumont and Hinnekint (1973) for the best known European migrant, Libellula quadrimaculata (Four-spotted Skimmer). Large migrations occur at ca. 10 year intervals, generally after very large mass emergences synchronized 
by delays due to cold spring weather. These authors hypothesized that large migratory swarms may result when non-adaptive movements are initiated because individuals that see others in flight are also likely to start flying and potentiated by internal irritation due to high trematode parasite loads. Haritonov and Popova (2011) described irruptive movements of this species in Siberia. Surprisingly, I have no unequivocal records of this species migrating in North America, although Calvert (1893), mentions its occurrence, without specific data.

\section{Life history and migration in Anax junius}

Phenology

Of all North American species, Anax junius is best known and clearly is a regular, annual migrant from southern Canada well into Mexico and perhaps beyond. Each year, in mid-August through October, reports of noticeable southward flights and large aggregations appear in natural history newsletters, the popular press, and sometimes in the entomological literature. Russell et al. (1998) compiled a long but far from exhaustive list of such accounts, noting that "Records of large dragonfly migrations show several distinct patterns: (1) all reports fell between late July and mid-October, with a peak in September; (2) most of the large flights occurred along topographic leading lines such as coastlines and lakeshores; (3) massive swarm migrations generally followed the passage of synoptic-scale cold fronts; and (4) the common green darner (Anax junius) was the principal species involved in the majority of these flights."

Migration studies in North America became more quantitative and focused with the work of Robert Trottier $(1966,1971)$ on Anax junius in southern Canada. He found that near Montreal $\left(\sim 45.5^{\circ} \mathrm{N}\right)$ larvae probably were unable to overwinter, although they are regularly found during summer (overwintering has now been shown to occur at least as far north as Montreal (Catling 2004), however, possibly in response to climate warming). In southern Ontario $\left(\sim 43.5^{\circ} \mathrm{N}\right)$, by contrast, two clear-cut cohorts of larvae existed, corresponding to adults with very different behaviors. Larvae of one group emerged from late June through mid-July and the resulting adults finished oviposition by early August. The other group appeared as small larvae in June, developed rapidly during the summer and emerged in late August through September after adults of the first cohort had died. The second group of adults mostly disappeared before maturing sexually. These observations suggested (Trottier 1971) that the first group of larvae represented "residents" that overwinter as larvae, mature and emerge by midsummer, become active as adults, oviposit and die by mid-August. Their offspring then hatch and grow to mid-instar larvae before entering diapause for the winter. The second larval cohort were the offspring of adults that migrate into the area in early spring and have been seen ovipositing in early April, while snow may still be on the ground (Walker 1958; Butler, et al. 1975). They grow rapidly as soon as the water warms and mature by late summer, emerge as adults, and mostly depart from the vicinity of their natal ponds while still sexually immature and migrate southward. Presumably some of their offspring return northward the next spring (although they may not return to the same pond, or even the same region, as their parents), and the migration cycle begins again. This scenario sees migration as a normal part of the life cycle that facilitates colonization of northern areas. It is consistent with many reports of apparently annual movements described along the eastern seaboard by Shannon (1916, 1935 ) and on the northern shores of Lake Erie by Walker (1958), Nisbet (1960), and Corbet (1984).

Wissinger (1988) reported a similar pattern of emergence, with two well-separated emergence periods, from a population of $A$. junius in northwestern Indiana in 1982-1984, although a few adults emerged early, in April. These were interpreted as individuals of the previous year's "migrant" cohort that had not completed development in time to emerge the previous fall and had diapaused over the winter. This suggests that larval diapause is facultative and supports the possibility that some early adults seen in northern localities may emerge locally (White and Raff 1970). Kime (1974) also reported "migrant" and "resident" cohorts of Anax junius larvae in Washington State, based on larval size distribution.

In sum, these results suggested that migrants and residents are behaviorally and physiologically distinct and, especially from Trottier's study, that the two cohorts might be reproductively isolated because the mating and oviposition periods of their respective adults did not overlap (Fig. 1a). The likelihood of genetic divergence of migrants and residents seemed high, and even the possibility of incipient speciation had to be considered.

Very little published work on developmental phenology has appeared since Wissinger's (1988) study, but unpublished studies reveal much more variability in the life cycle of Anax junius. During nine years of daily collections of exuviae at a pond in New York $\left(\sim 42.42^{\circ} \mathrm{N}, 76.83^{\circ} \mathrm{W}\right)$, John and Sue Gregoire (pers. comm., 2012) found a weak tendency toward a bimodal peak of emergence but with no complete hiatus in emergence during the summer and great interannual variation in emergence pattern and total numbers emerging. A similar pattern of bimodal emergence with substantial overlap of early and late peaks was seen at Patuxent Research Refuge in Maryland $\left(39.04^{\circ} \mathrm{N}\right.$, $76.78^{\circ} \mathrm{W}$; Orr 1996; pers. obs., 1999-2004) and from the 

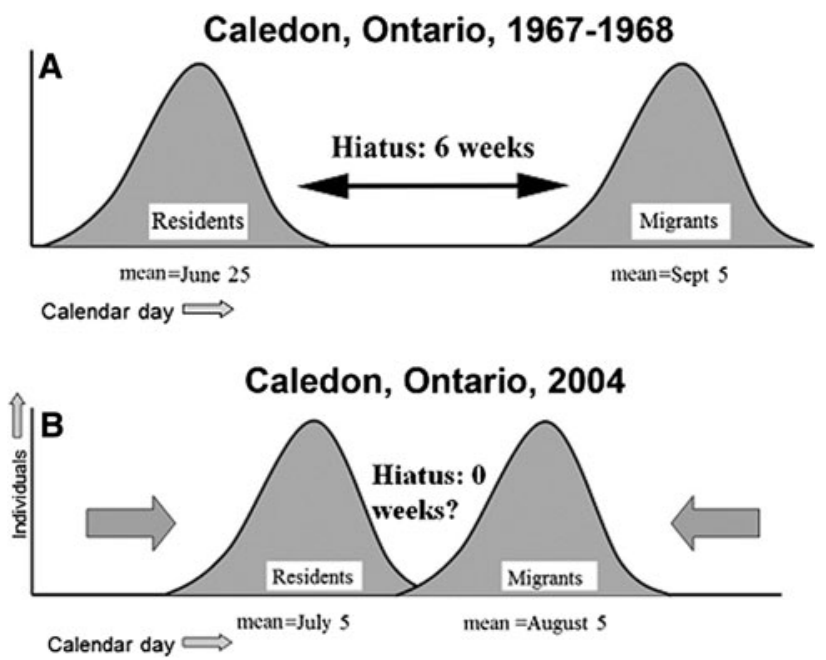

Fig. 1 Schematized emergence patterns of Anax junius at a pond near Caledon, southern Ontario, Canada, a during the summers of 1967-1968 during the study by Trottier (1971), and b during the summer of 2004 (Matthews 2004, 2007a, b). Modified from an unpublished figure by J. Matthews, used by permission of the author

state of Washington (Kime 1974). Data are still scanty from the southern part of the range. Paulson's (1999a) observations in southern Florida suggest a major period of emergence in March and April, followed by reduced activity until an influx of adults in late summer, with a minor peak of emergence in October (Fig. 2). More extensive data on adult flight season, based on specimens in the Florida State Collection of Arthropods, confirms that in Florida few adults occur from late May until early August (May, unpublished data, 2012). Still, some may be found flying at any time of year and final instar larvae apparently are present throughout the summer (N. Dorn, pers. comm., 2010). Data from Austin, Texas (J. Matthews, pers. comm., 2011) also indicate an early spring emergence peak but are incomplete and thus not definitive concerning fall emergence. Finally, Matthews (2004, 2007a, b) revisited the area in Ontario where Trottier had worked almost 40 years before and discovered that, while the bimodal emergence pattern persisted, emergence peaks overlapped extensively and some emergence continued through the summer (Fig. 1b). He tentatively ascribed this to changes in local precipitation patterns. Thus the picture of clear cut migrant and resident cohorts turns out to have been a considerable oversimplification that varies spatially, has changed over time on a scale of decades, and may be much more variable annually than was initially realized.

\section{Tracking fall migrations}

Besides these new perspectives on Anax life history, recent studies add critical data and unique insight into individual behavior. Wikelski et al. (2006) attached micro-radio

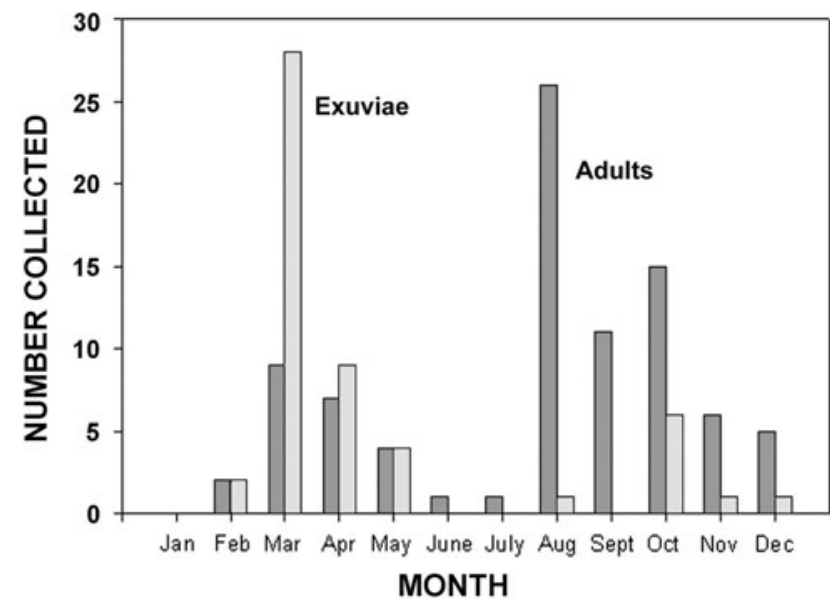

Fig. 2 Numbers of adults and exuviae of Anax junius collected by Paulson during 1958-1965, by month; pale bars indicate numbers of exuviae, dark bars numbers of adults. Derived from data given in Paulson 1999a, used by permission of the author

transmitters to 14 A. junius and followed them during fall migration for up to 12 days (Fig. 3). Despite carrying transmitters, individuals migrated up to $140 \mathrm{~km}$ per day, and two were observed foraging apparently normally. The dragonflies alternated distinct stopover periods with active migration and on average migrated about every 3 days. The average advance of 13 migrating individuals was approximately $60 \mathrm{~km}(12 \mathrm{~km} /$ day $)$, but daily movement ranges exhibited a trimodal distribution: short-range and omnidirectional and medium or long-range and, on average, within a few degrees of due south, as suggested by Russell et al. (1998).

Three individuals in Wikelski's study changed their migration route by more than $120^{\circ}$ upon reaching an ocean barrier (Fig. 3), evidently reorienting in response to landmarks (although some do perish at sea during migrations along shore; pers. obs., 1993). Three captured at Cape May returned northward, later to cross Delaware Bay at a narrower point, indicating considerable behavioral flexibility in route selection. Songbirds and small hawks sometimes perform a similar maneuver during fall migration (e.g. Wiedner et al. 1992).

Data from Wikelski et al. (2006) were limited by the small numbers that could be tracked, the necessity of encumbering the insects with a load of around $25 \%$ of their body mass, and the inability to track individuals more than 100-200 km from the release point. These difficulties were largely overcome by Matthews (2007c; May and Matthews 2008), who took advantage of a well-documented north to south gradient in the ${ }^{2} \mathrm{H}:{ }^{1} \mathrm{H}$ isotope ratio in natural fresh waters. This ratio is reflected in hydrogen isotope ratios of resident aquatic animals, including odonate larvae (Hobson et al. 2012), and is preserved in the relatively inert wing cuticle of adults. Carefully calibrated 


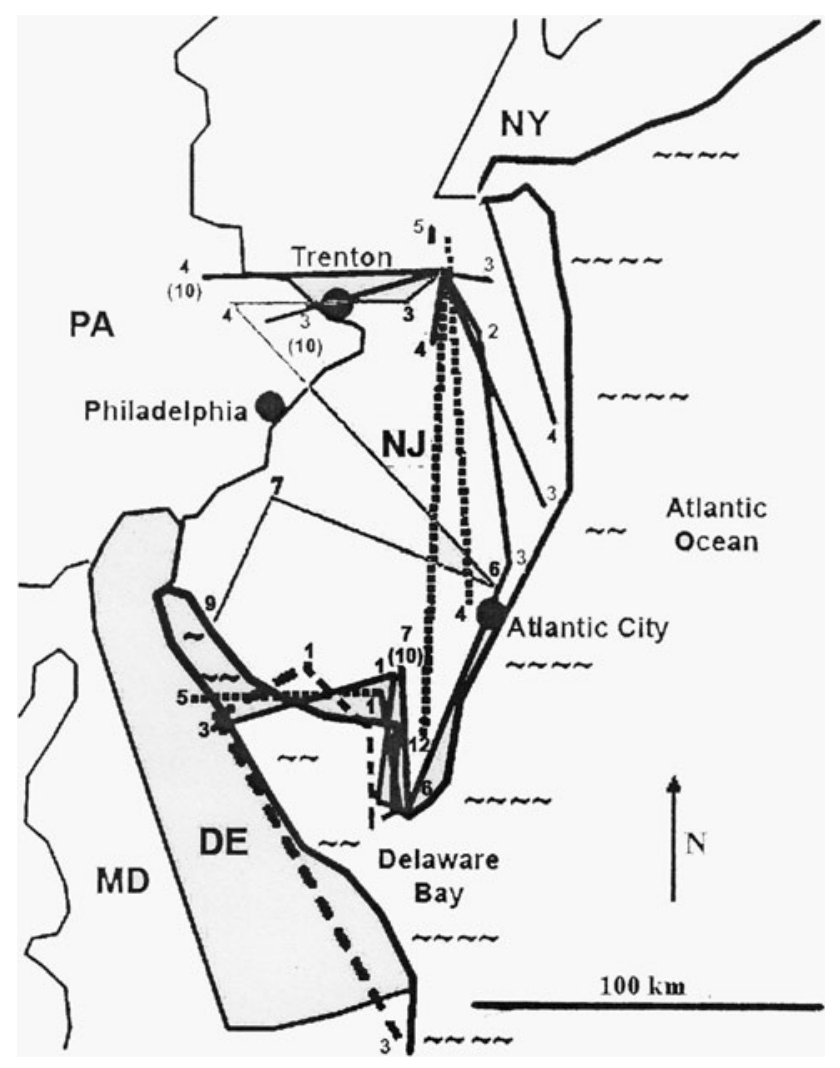

Fig. 3 Flight tracks of 13 radio-tagged Anax junius in Fall 2005 in New Jersey. Each line represents a separate individual; numbers depict days since tagging, numbers in parentheses show maximum number of days individuals were tracked, broken lines indicate uncertainty about which day individuals conducted their migratory flight. Tilde symbol indicates open water. From Wikelski et al. (2006). Used by permission

${ }^{2} \mathrm{H}:{ }^{1} \mathrm{H}$ ratios of individuals collected along a transect from Ontario, Canada, to Veracruz, Mexico, during late August to October, revealed that about $90 \%$ of individuals moved southward, by a mean distance estimated at ca. $900 \mathrm{~km}$, with a maximum of nearly 3,000 km (Matthews 2007c). Moreover, using both hydrogen and strontium isotope ratios, Matthews showed that individuals collected together in localized swarms near the Atlantic Coast mostly had originated at inland sites, possibly spread far northward and westward. It seems clear that Anax junius migrate southward over at least many hundreds of $\mathrm{km}$. Observations by Matthews (2007c) and others (Russell et al. 1998; Wikelski et al. 2006) suggest that this movement is punctuated by episodes of feeding and reproduction, probably at many sites along the migratory route, so migrants may spend many weeks en route.

Direct observations of feeding by presumed migrants are common, and Wikelski et al. (2006) compared the alternation of periods of short flights with days of long-distance flights to "refueling" stops well known in many migratory birds. Anax junius may spend as much or more time

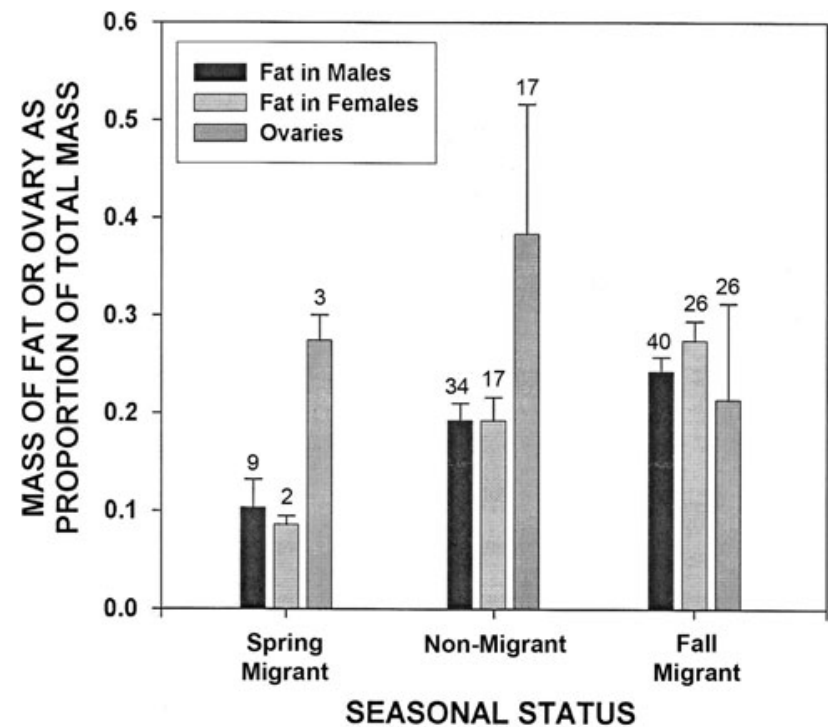

Fig. 4 Proportional fat and ovary mass in Anax junius under varying conditions in New Jersey; numbers above each bar are sample size. Modified from May and Matthews 2008

feeding in local areas as actually making long flights of many of kilometers. Clearly energy accumulation and suitable feeding sites are important to these migrants. Anax, like other Odonata, eclose with very little fat, undeveloped ovaries and functional but incompletely developed flight muscles. They quickly increase muscle mass and fat stores, and both in local breeders and migrants, body mass comprises at least $20 \%$ fat, on average (May and Matthews 2008). This is significantly higher than in non-migratory Anisoptera (Anholt et al. 1991; May, unpublished data), and fat content of fall migrants is significantly higher than in local breeders (Fig. 4). Even so, Wikelski et al. (2006) calculated that without wind assistance the average fat reserves of an individual would only last for one full day of flight. Spring migrants in New Jersey apparently have low fat content but large ovaries (May and Matthews 2008), although few specimens have been analyzed. This pattern, if confirmed, suggests that migrants arrive at northern locations reproductively mature but with depleted energy reserves.

Reproductive activity en route is less frequently observed directly. Both Corbet (1984) and Catling and Brownell (1998) found that virtually all A. junius collected in late August through early October along the north shores of Lakes Erie and Ontario were immature; this is near the northern limit of the range where the species is common, although it reproduces sparsely as far as $50^{\circ} \mathrm{N}$ (Walker 1958). In Cape May, New Jersey, and along the south shore of Long Island, New York (ca. $\left.40^{\circ} \mathrm{N}\right)$, however, tandem pairs (i.e., with the male grasping the female, which almost always indicates an imminent or ongoing bout of oviposition) are a minor component of some migrating swarms 
(Walter 1996; Russell et al. 1998), and many females collected at Cape May have mature ovaries (Fig. 4). During a Florida migration, all specimens appeared mature based on visual criteria, and scattered tandem pairs were observed (Russell et al. 1998), and Matthews (2007c, and pers. comm., 2006, 2011) observed tandem and ovipositing pairs along the Virginia and Texas coasts and in Veracruz, Mexico. Moreover, the genetic composition of A. junius populations permits the inference that reproduction is a common feature of migration in that species. Sexually mature migrants are expected if they depend on reproductive bet-hedging by ovipositing repeatedly during the southward flight as suggested below (Matthews 2007c; May and Matthews 2008).

Population ecology and genetics

In the first genetic survey of the species Freeland et al. (2003 sequenced most of the mtDNA protein coding gene, COI, from adult specimens collected across the continent and from Canada to Mexico. They found a diverse complement of haplotypes, but none that characterized migrant vs non-migrant individuals. They suggested that this could be the result of the mixing, during migration, of numerous sub-populations that varied in haplotype owing to local selection. Nothing indicates that migration itself was genetically controlled, however, since migrants and nonmigrants shared haplotypes and migrants were not concentrated in particular clades.

Matthews (2007c) collected both adults and larvae along an irregular transect across much of eastern North America. Examination of nine microsatellite loci gave little or no evidence of geographic genetic differentiation or of differentiation between presumed migrant and resident individuals of either life stage. Larvae showed some tendency to be more closely related within collection sites but not among nearby sites, and even within-site relatedness could be explained by the existence of sibling groups from a single year. This strongly supports the conclusion that ponds are populated and repopulated annually by offspring of adults of widely separated origins, as would be expected in species that reproduce freely during the course of wideranging dispersal.

The observed haplotype diversity (Freeland et al. 2003) could indicate selection on local populations, since mixing of the continent-wide population makes it unlikely that drift is a major factor. Local populations might be displaced from selective equilibrium by repeated influxes of migrants, as well as instances of catastrophic habitat collapse. Either or both might limit adaptation to local conditions and favor evolution or maintenance of facultative migration. Of interest would be data from the presumably non-migratory population of Anax junius in Hawaii, in which both local selection and perhaps drift between subpopulations on different islands might have greater effects.

The origin and destination of southbound migrants can only be indicated in broad terms, largely because the beginning and end points of migration are, in fact, very widely dispersed. Matthews' (2007c; May and Mathews 2008) data on hydrogen isotope ratios, described above, together with the genetic evidence, indicate that fall migrants are drawn from a huge region extending from as far as $50^{\circ} \mathrm{N}$ to as far south as $\sim 33^{\circ} \mathrm{N}$ and from the Atlantic Coast far inland, and other evidence suggests that individuals from the Pacific Northwest probably migrate extensively through the western US (Kime 1974; Paulson 1996). Individuals from large areas mix in adult aggregations and probably lay eggs in ponds along much of their route. The ultimate southward extent of flights is unclear, but based on my observations on the east coast of northern FL (Russell et al. 1998), and those of Matthews (2007c) and others (Paulson, pers. comm, 1999; Tibol, pers. comm., 2008) in Veracruz State, Mexico, substantial numbers, probably millions, reach those points and beyond. The Florida data fit neatly with those of Fig. 3 showing a sharp increase in the number of adult Anax in southern FL during August to October, with little evidence of emergence until October. Anax junius is also known from the Greater Antilles, but whether these represent strays, regular migrants, or resident or partly-resident populations is unknown. In Mexico and Central America, Paulson (1984, 1999b) and Boomsma and Dunkle (1996) believed that $A$. junius seen in the Yucatan and Veracruz, and in Belize, in October and November were North American migrants, and observed evidence of reproduction, including tandem pairs and oviposition.

\section{Spring migrations}

Large migrating swarms of A. junius are seen with some regularity in autumn but much more rarely in spring. Clearly, if migration is annual and an adaptive life history strategy, northward spring migration is implied. Evidence for this includes that cited above, i.e., observations of mature individuals that initiate reproductive activity in northern areas in early spring at places where they apparently could not have emerged (Walker 1958; Young 1967; Butler et al. 1975). On the other hand, White and Raff (1970) found exuviae in central Pennsylvania that suggested that some of these early individuals might emerge locally and Wissinger (1988) as noted already, documented early emergence in Indiana.

More recent and systematic observations in the northeastern U.S. have adduced additional evidence for spring migration. At many sites, substantial numbers of Anax junius appear with warm air masses in early spring, 
generally remaining at a given site for only a few days (R. Barber, A. Barlow, B. Nikula, R. Orr, pers; comm.; pers. obs.). More details of one such influx are described by Russell et al. (1998). Other compelling evidence for the occurrence and regularity of spring migration northward is the fact that, in eastern Maryland, the mean appearance date of the first mature adults in 1991-1995 was 6 April (range 24 Mar. to 25 April) while the average first emergence date was 26 May (range 7 May to 11 June; Orr 1996) and in southern New York from 2004-2009, adults appeared on average on 26 April (23 April to 7 May) while mean first emergence was on 9 June (25 May-15 June; S. Gregoire, pers. comm, 2011).

Apparently, large swarms of Anax rarely if ever form in the Northeast at this time, although distinct migratory swarm of other species may include some Anax junius (e.g., Sones 1995; observed on Cape Cod in early June). The near absence of spring swarm migration may be related to one or more of the following phenomena, which are not mutually exclusive: the total number of adults moving northward may be less than those that fly south, since mortality must be high in both directions, and the relative reproductive success during the northern summer vs. fall to early spring in southern parts of the range is not known; it is possible that spring migration is more protracted (see below); and, because warm fronts commonly move more nearly parallel to the SW-NE orientation of the Atlantic Coast than do cold fronts, the spring migration track may often not intersect the coast, where migration would be most obvious due to leading line effects (Russell et al. 1998). The origin of northward migrants is even less clear. It is generally assumed that those arriving in early spring in southern Canada and the Northeastern and Midwestern U.S. have mostly emerged in the southern U.S. (Butler et al. 1975), perhaps supplemented with a few early local emergers (White and Raff 1970; Wissinger 1988). This scenario is consistent with the emergence phenology seen in S. Florida (Fig. 2) and in Austin, Texas $\left(30.3^{\circ} \mathrm{N}\right.$; peak usually in late April to early May; Matthews, pers. comm., 2006). Other sites from which data are available are located no further south than $38^{\circ} \mathrm{N}$ and are unlikely to produce new adults early enough for these to reach Canada by early April (Butler et al., 1975). Unfortunately, isotope ratio data for adults arriving early at northern sites in spring are not yet available, although even as late as early September, Matthews (2007c; May and Mathews 2008) recorded apparent northward movements of a few individuals from stations along his transect. He surmised that northward movements might continue with moderate frequency throughout the spring and summer. It seems, however, that long, directed flights are likely at the beginning of the northern season, given that the first mature spring migrants appear at times when emergence probably has barely begun even several hundred kilometers further south. This could, perhaps, give the resulting larvae a size advantage over the offspring of later arriving adults while avoiding high rates of cannibalism by large overwintering larvae owing to cool water temperature (Crumrine 2010).

\section{Other migrants in temperate North America}

A surprising variety of dragonflies, mostly Libellulidae and Aeshnidae, are observed occasionally in swarms that include known regular migrants moving in a constant direction (see, e.g., Russell et al. 1998, in the US and Canada; Paulson 2002, in Mexico). Given the facultative nature of migration in Anax junius, small numbers of other species may also undertake latitudinal migrations, perhaps annually, although the nature and function of these movements requires further study.

Be that as it may, in addition to A. junius, an aeshnid, at least four libellulid dragonflies are regular and often prominent migrants: Tramea lacerata (Black Saddlebags), Sympetrum corruptum (Variegated Meadowhawk), Pantala hymenea (Spot-winged Glider), and P. flavescens (Wandering Glider). The first three of these species have not been studied carefully. Corbet and Eda (1969) found that $T$. lacerata was present in some numbers among migratory or pre-migratory aggregations of A. junius at Point Pelee and elsewhere in southern Ontario in late summer. They are also frequent among A. junius aggregations at Cape May, New Jersey, and have been observed apparently setting off across the Delaware Bay at this site. The emergence pattern of T. lacerata in Indiana was similar to that of A. junius except for the absence of the small, early spring peak (Wissinger 1988). These data suggest that its behavior and migratory strategy may be similar to those of Anax. All Tramea spp. appear to be physically adapted for gliding flight, and thus potentially for migration, by virtue of their broadly expanded hindwings, and extreme vagrancy [e.g., T. calverti, in the Northeastern United State (Soltesz 1992)] and large swarm migrations in the tropics have been recorded [e.g., T. basilaris, in Africa (Dumont 1977; Pinhey 1979)].

Sympetrum corruptum is an abundant, small libellulid found throughout western North America. It migrates southward en masse along the Pacific Coast of the Western United States from southern Washington to central California (Macy 1949; Koehler 1965; Opler 1971; Arnaud 1972; Bayer 1997), and its closest relative may be the wellknown Old World migrant, S. fonscolombii (Pilgrim and van Dohlen 2012). Migrations are probably annual but seem to vary markedly in numbers from year to year. In virtually a mirror image of the pattern shown by Anax junius in the east, they are usually observed along the coast 
during easterly or northeasterly winds, flying south- or southeastward (thus across the wind). Some may be blown out to sea-Paulson (pers. comm., 2009) found many in the stomachs of salmon caught offshore in Oregon. Mass flights are occasionally observed also in the Cascade Mts. in Washington and the Coast Ranges farther south. Smaller numbers of A. junius and $T$. lacerata are sometimes observed with swarms of $S$. corruptum. Little is known of the species' life history, and information on migration consists almost entirely of anecdotal reports of mass flights. Reproductive activity has been observed in southern Texas in mid-winter, so it is plausible that the offspring of these breeders return north in spring, but no direct evidence exists. Individuals also may wander widely, as scattered specimens have been taken in nearly every US state and across southern Canada (Odonata Central 2012a).

Pantala hymenaea often appears, usually in small numbers, rather abruptly as mature adults in the northeastern US in midsummer, and this species has been reported as a prominent migrant in Mexico, especially near the coast in Veracruz State (Paulson 1999b; pers. obs., 2011) and in Venezuela (De Marmels et al. 2008).

Energy stores and reproductive condition of these migrants have been little studied. Corbet (1984) found that the great majority of presumed migrant species in Ontario, except Sympetrum vicinum but including T. lacerata, among others, were pre-reproductive and apparently laden with fat. At Cape May, New Jersey, in the fall, most T.lacerata are immature (pers. obs.).

In some years large numbers of several species (Epiaeschna heros, several species of Libellula, Pantala spp., Tramea lacerata, T. carolina) may appear in spring as mature adults before evidence of local emergence (Soltesz et al. 1995; Sones 1995; Paulson, pers. comm, 2011), but it is not clear that these are annual movements; among these, Libellula axilena, L semifasciata, and $L$. vibrans have not been noted as fall migrants.

Erythrodiplax funerea and E. umbrata (Black-winged and Band-winged Dragonlets) are two largely tropical libellulids that reach the southern United States and are often described as migrants. In their tropical range, these species spend most of the dry season in forests away from water and then have dull bodies and nearly unmarked wings. With the onset of seasonal rains, males and some females turn black with striking black areas on the wings and move into more open areas to breed in lakes and ponds, often temporary ones (Dunkle 1976; Morton 1977). In some instances, large numbers apparently may fly for considerable distances to breeding sites. Most of these movements correspond to what Corbet (1999) called seasonal refuge flights, which occur when adults emerge near or after the end of the reproductive season, fly into forest or even into distant uplands, and spend the unfavorable hot, dry season in reproductive diapause. When conditions are more favorable, they return to suitable sites for reproduction. This behavior functions similarly to latitudinal migration in that the behavior moves individuals seasonally from less to more favorable habitats, but it differs in that the same individuals complete the round trip, and emergence and reproduction are separated by a relatively long period of reproductive quiescence. A number of other tropical Odonata may have similar life histories (Corbet 1999; pers. obs.).

\section{Pantala flavescens, a tropical wanderer}

Another well-known migrant, found throughout the Tropics and extending well into the North Temperate Zone in North America and Asia, is Pantala flavescens. The common name of this species, Wandering Glider, is truly descriptive, for adults apparently wander freely with the prevailing winds, and their broadly expanded hind wings adapt them for long periods of gliding with minimal effort. Although their behavior and population biology has not been studied carefully in North America, nearly all populations of this species probably are obligate migrants, with successive generations breeding hundreds or thousands of kilometers from their places of emergence. The species is adapted in the Tropics to follow prevailing winds to the Intertropical Convergence Zone (ITCZ), where rainy conditions and consequent formation of temporary ponds are likely (Corbet 1999). This tendency to become entrained in persistent winds doubtless is one reason they are among the Odonata most often found in swarms well out to sea and have reached isolated islands such as New Zealand (Corbet 1979) and Easter Island (Moore 1993; Samways and Osborn 1998).

Pantala flavescens is also the only dragonfly species known with certainty to migrate sometimes at night. They were observed with searchlight traps and radar, flying in large numbers over the Bohai Sea of eastern China on several nights over two summers (Feng et al. 2006). During late July and August, flight direction was generally southwestward, even in opposing winds, but during June most flew northwest to east-northeast.

Various threads of the migratory behavior of $P$. flavescens in the region of the western Indian Ocean have been very skillfully woven together by Anderson (2009). His initial observation was that $P$. flavescens (along with much smaller numbers of other known migrants) first appear in the Maldives in early October, just before the ITCZ normally crosses the area on its southward excursion. Large numbers arrive in late October. Like A. junius, some are sexually mature, in tandem or ovipositing, although the virtual absence of fresh surface water in the Maldives 
prevents successful breeding. The same abundant species migrates southward in India, arriving in the southernmost part of the subcontinent in September and October ahead of the northeast monsoon (Fraser 1936; Larsen 1987). Although surface winds in the Maldives are mostly westerly when they first arrive, upper level winds are principally from ENE, as the ITCZ front inclines southwestward with increasing altitude. Anderson concluded that the influx was carried by upper level winds from India for $600-1,000 \mathrm{~km}$ to the Maldives. Since they cannot breed there, they must either perish or continue on to Africa. The evidence that they do so is more circumstantial, but large influxes in the Maldives are commonly followed by gradually diminishing numbers until another influx arrives, and large numbers of Pantala appear first in more westerly islands (where breeding may occur, as in the Seychelles; Samways 1998) and eventually in East Africa beginning in late September and throughout the summer wet season (e.g., Pinhey 1979). Some of these may be from further north in Africa, but a plausible inference, given their timing, is that many make the transoceanic crossing of up to $4,000 \mathrm{~km}$ from India to Africa.

Large numbers of Pantala reappear in western India in June to July, associated with strong westerly winds known as the Somali Jet, generally preceded by a small influx to the Maldives in May. Based on careful correlation of dates and places of appearance, it seems likely that in the northern autumn and early winter, $P$. flavescens follow the ITCZ on northeast winds across the western Indian Ocean from southern India to Africa, where they reproduce. Their descendants move north and east in spring with the northward return of the ITCZ and the associated Somali Jet (Fig. 5). This hypothesis is strengthened by the knowledge that larval development is extremely rapid in this species (Kumar 1984; Suhling et al. 2004; Suhling, pers. comm, 2011) in temporary rain pools.

The presence of $P$. flavescens well north of the tropics requires some explanation. In East Asia, owing to summer heating of the huge Asian landmass, the northward excursion of the ITCZ extends far enough to account for their presence in summer in Japan and northeastern China (Johnson 1969). In North America, however, they apparently overshoot the ITCZ by hundreds of $\mathrm{km}$. It is likely that larvae are unable to overwinter as far as $40^{\circ} \mathrm{N}$ (Wissinger 1988), and adults commonly appear no earlier than late June (pers. obs., supported by records from Odonata Central 2012b). In some instances, particularly along the Atlantic Coast, they may be entrained in the outer winds of hurricanes and transported well northward (Paulson 1999a; Soltesz, pers. comm, 1993). This is cannot account for their annual appearance well inland, however. More likely they move northward, perhaps carried in summer by the prevailing southwesterly air flow, from populations in

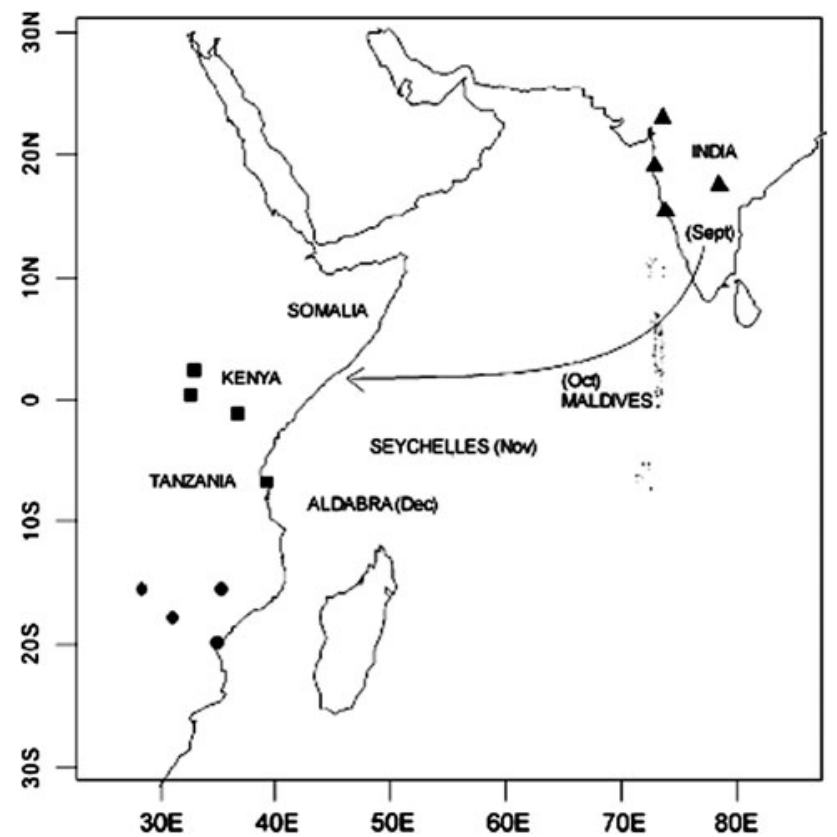

Fig. 5 Map of region including, India, the Indian Ocean, East Africa, and the Arabian Peninsula, across which Pantala flavescens is thought to migrate (see text). Normal months of arrival at different island groups in the western Indian Ocean are given in parentheses. Symbols are location of weather station from which monsoon movement and rainfall data were obtained. Arrow indicates schematic track of crossing of $P$. flavescens that pass over Male, Maldives, during migration from India to Africa. From Anderson 2009; used by permission of the author and Cambridge University Press

northern Mexico and the southernmost United States (where larval development, or at least survival, is probably possible during the northern winter) and/or are brought into this flow by Atlantic trade winds from northern South America or the Caribbean. In Southern Africa P. flavescens and some other Afrotropical migrants may not be entirely dependent on seasonal winds but undergo 'diffuse migration', during which they may wander into habitats unsuitable for breeding (Samways and Caldwell 1989); moreover, they sometimes depart localities in that region even though suitable pools remain (Samways, pers. comm., 2012). Similar wandering by $P$. flavescens and $P$. hymenaea may take place in North America, although no data as yet support this possibility.

The energy status of migrant $P$. flavescens is uncertain. Individuals may fly nonstop for multiple days over regions, including expanses of ocean, where feeding may be difficult and reproduction impossible. This species can compensate for wind drift and optimize flight speed in response to wind speed so as to minimize flight costs (Srygley 2003; Srygley and Dudley 2008), so it is possible that they do not feed on trans-oceanic portions of the flight but do so during pauses at islands like the Maldives and especially those like the Seychelles, where opportunities for reproduction exist (Samways 1998). They also locate and feed on 
concentrations of "aerial plankton" (Russell and Wilson 1997), along localized sea-breeze fronts moving overland near coastal zones. Whether similar concentrations exist along the ITCZ front over open ocean is unclear; if present, they could represent a source of energy during ocean crossings.

Nothing is known of genetic structure, if any, in $P$. flavescens, although Samways and Osborn (1998) provide evidence of isolation and some differentiation in the isolated, and presumably non-migratory, population on Easter Island. If the current picture of its transcontinental movements in the Indian Ocean region applies generally, populations can be expected to experience intense genetic mixing and perhaps also reduced local selection compared to A. junius, because of its extremely ephemeral larval habitat. On the other hand, if migration routes are as stable as hinted at by Anderson's (2009) work, it is possible that a few very large intercontinental populations might exist between which connectivity is appreciably less between than within populations (J. Ware, pers. comm., 2011). In particular, those in North and South America may be relatively isolated from those using the South Asian-East African and the East Asian migratory routes.

\section{Climate, climate change, and migration}

Migration is generally an adaptation to avoid seasonally unfavorable climate or a response to mass emergence brought about by unusual weather or to population increases in response to favorable weather conditions in arid regions (Dumont and Desmet 1990). Typically, migration by insects in mid- to high latitudes is a means of avoiding cold winter temperatures, whereas in the tropics, it is usually seasonal drought that must be circumvented. Most migrant dragonflies in cool temperate North America are members of genera or species groups that are tropical in origin, and their behavior and life history may partly reflect their tropical ancestry, but their environment necessitates new adaptations. In many temperate zone species, larval diapause is an alternative to adult migration, and in tropical species, adult diapause may provide a means of surviving dry periods, but thermoperiod and hydroperiod are the essential drivers and enablers of dragonfly migration.

On the time scale of an adult's lifetime, however, migratory tactics in either case are highly dependent on locating and exploiting favorable winds that move the migrant toward thermally favorable regions with suitable aquatic breeding sites when they arrive. Most dragonflies migrate, at least in part, within their boundary layer (Johnson 1969; Taylor 1974), and can make headway against the wind, but even strong fliers, which can compensate for wind drift (Srygley 2003; Srygley and Dudley
2008), nevertheless move mostly with prevailing winds. This is perhaps clearest for $P$. flavescens, and has been noted also by Dumont $(1977,1988)$ and Dumont and Desmet (1990) in Anax (= Hemianax) ephippiger. At least Pantalaflavescens and Anax ephippiger also may fly at great height (Corbet 1984; Feng et al., 2006; Anderson, 2009), taking advantage of upper level winds.

Pantala flavescens depends on both wind and rainfall associated with the Indian northeast monsoon. Effects of future climate change on these events are likely to bring higher temperatures and more variable rainfall (Goswami et al. 2006). Currently there is no clear evidence for changes likely to have severe adverse effects on $P$. flavescens or its migratory behavior, although the possibility of decreasing rainfall in East Africa (Williams and Funk 2011) could be of some long-term concern in that region; even if severe, however, this seems unlikely to pose a major risk to such a widespread and mobile species.

Southward movements of A. junius in autumn are correlated with northerly winds after passage of cold fronts (Russell et al. 1998; Wikelski et al. 2006), as northward movements in spring are with southerly air flow. Coupled with the ability to avoid dangerous situations such as flying out to sea, this may in itself suffice to bring migrants to seasonally suitable habitats. Wind driven flights must occasionally lead to maladaptive dispersal, however, such as the appearance in 1998 of Anax junius in Cornwall, UK, probably forced eastward across the Atlantic in strong WSW winds associated with the remnants of two successive hurricanes that swept up the east coast of the United States a few days earlier (Pellow 1999; Davey 1999). The timing of migration is also related, although perhaps less strictly than in P. flavescens, to the hydroperiod of regions of origin and destination. Precipitation is typically distributed fairly evenly throughout the year in northeastern North America, and, even if modestly higher in summer, rapid summer evapotranspiration results in low water levels in much of this area in late summer, with concomitant dangers of desiccation or overheating and low oxygen levels in ponds. Thus migrants may emerge during or just before periods of potential stress for larvae. By contrast, in Florida, the southeastern Atlantic Coast, and the U.S. and Mexican Gulf Coast, marked peaks of rainfall generally occur from June to late summer, with water levels likely to be at or near their highest in early fall (e.g., Abtew et al. 2006). Consequently, migrant $A$. junius arrive near the time when suitable oviposition sites are most readily available. Obviously, serious drought or changes in rainfall patterns, especially in destination regions, might affect the pattern and overall success of the migrant strategy. Seager et al. (2009) modeled precipitation in the Southeast up to 2100 C.E. and found little likelihood of severe drying. Even if drought were to occur, the facultative nature of migration 
and the apparent ability of Anisoptera, especially highly mobile species, to successfully shift their ranges northward suggests that migrant species are relatively secure, although the migration phenomenon might undergo significant change.

\section{Global patterns?}

Leaving aside the seasonal refuge flights described earlier, continental scale migrations may loosely fit one of two distinct but partly overlapping patterns, corresponding roughly to the strategies of Anax junius on one hand and Pantala flavescens on the other. In the first case, species probably evolved from tropical ancestors [e.g., North American Anax, Tramea, and perhaps S.corruptum (Pilgrim and van Dohlen 2012) belong to mostly tropical genera] but have adapted to permanent occupation of temperate habitats, i.e., larvae can overwinter in facultative diapause. Their larval habitats are stable enough to produce annual generations for at least several successive years, but the numbers from a given pond may fluctuate over almost an order of magnitude from year to year (based on daily collections of exuviae from a single pond throughout the entire emergence season from 2004-2012; J. and S. Gregoire, pers. comm., 2012). Furthermore, many ponds in late summer are subject to drying and other stressors serious enough to extirpate local populations in some years (Matthews, pers. comm., 2007; pers. obs, 2004). This insures that these ponds are largely free of predaceous fish, but they become entirely unsuitable for odonate development at unpredictable intervals. Such catastrophic lateseason events probably favors reproduction in several different water bodies by late-emerging adults as a hedge against loss of all offspring and dispersal over relatively long distances in, e.g., cases of regional drought. This should also favor rapid development in larvae that that hatch in spring, in order to minimize the risk of late season mortality; Crumrine (2010) proposed that larvae that are about 3-5 instars short of emergence in late summer may take greater risks in attacking large prey in order to accelerate development. Smaller larvae that hatch in midsummer and could not leave the pond before the onset of winter should remain and diapause, based on reasonably favorable odds that the habitat would remain suitable. Such a strategy might be enhanced if larvae could respond to early signs of developing adverse conditions. Warming of ponds in late summer in itself could accelerate development.

Late-emerging adults risk encountering cold weather before they can reproduce, especially in the north of the species' range, so flying southward would be favored. As described above, this would be aided by the increasing prevalence of northerly air flow and might also have the advantage of bringing at least some of the incipient migrants into the moist subtropics near the end of the wet season, when hydrologic conditions might be at their most favorable for successful reproduction. Northward flight in spring would presumably be favored by the southerly surface winds that prevail then and, in some southern areas, by the risk of drying of ponds near the end of the winter dry season. In both cases migrants probably feed frequently en route and attain sexual maturity long before the end of migration and may mate and oviposit repeatedly at several different sites.

ITCZ migrants like Pantala flavescens are essentially tropical species that evidently do not diapause as larvae. They are adapted to constantly but somewhat predictably shifting conditions of water availability as seasonal rains progress alternately northward and southward through the year. Because surface winds track the ITCZ less reliably than do upper level winds, owing to lags (Anderson 2009) or local perturbations, these migrants are perhaps more likely to fly high, often above their flight boundary layer (Corbet 1984, 1999; Anderson 2009). If flying overland, they could descend each evening (Corbet 1984, 1999) and probably feed at that time, allowing them to mature as they progress. When flying over water, e.g., crossing the western Indian Ocean as Anderson (2009) suggests, however, they possibly cannot land for days at a time. This may explain the observations of Feng et al. (2006) of nocturnal migration of $P$. flavescens over the Bohai Sea in China. It may imply that feeding is difficult or impossible, inhibiting sexual maturation and selecting for reduced flight costs enabled by the broad based wings so characteristic of Pantala and Tramea. Alternatively, other flying insects may be available to high-flying ITCZ migrants; Feng et al. (2006) actually discovered the nighttime flights of $P$. flavescens while studying simultaneous migrations of moths, and numerous moths migrate at altitude during late summer in the northern hemisphere (e.g., Chapman et al. 2008). Anderson (2009) observed attempted reproduction in the Maldives, but whether these individuals matured en route or before departing from India is unknown. Interruptions of migration, accompanied by feeding, may occur in P. flavescens as described above and by Anaxephippiger, another apparent ITCZ migrant, when they arrive at mountain barriers before temperatures have warmed enough in the higher reaches to allow them to proceed (Dumont 1988; Dumont and Desmet 1990).

Migrants tracking the ITCZ most commonly breed in ephemeral pools formed by the prevailing rains, where predation pressure and competition are nearly absent, although larval competition with other dragonflies, especially other migrants that inhabit similar ephemeral pools, can affect survival (Samways 1998). Such water bodies are 
short-lived and warm, so development of the immature stages of the associated dragonflies must and can be quite rapid. Minimum development time, from oviposition to emergence in Pantala flavescens is as little as 30 days (Suhling, pers. comm., 2011), placing them among the most rapidly developing Anisoptera known (Kumar 1984; Corbet 1999; Suhling et al. 2004). Even so, these habitats may disappear in only a matter of weeks, sometimes before larvae can emerge successfully (Suhling et al. 2004), so there is essentially no chance for a "resident" life history strategy to occur [although at least one case is known of a $P$. flavescens larva surviving complete desiccation (Van Damme and Dumont 1999)]. Likewise, such species are not migrating simply as a bet-hedging strategy, since the chances are high that they could not successfully reproduce at the site where they develop. Even when migrating overland, oviposition along the route in arid regions at long distances away from the ITCZ itself might be detrimental because of the higher likelihood that water bodies, having already begun to diminish, might dry up before larval development is complete. It may be possible, however, for adults to spread risk within a limited region by mating and ovipositing at several pools once a region of active rains is reached, or even to track the convergence zone for a period of weeks as it gradually moves northward or southward.

\section{Concluding remarks}

Our understanding of dragonfly migration has advanced remarkably within the last six to eight years, but clearly the descriptions above are only preliminary sketches of the whole story. Among many questions that deserve further investigation are the following:

What is the impact on aquatic ecosystems of the seasonal departure and influx of large numbers of one of the top predators (i.e., dragonfly larvae) in many such systems, especially those without fish?

Do species and populations other than P. flavescens in Southern Asia/East Africa (Anderson 2009) regularly make long (multiple days) over-water crossings? If so, how do they replenish energy, if at all, en route?

Do overland ITCZ migrants regularly stop to feed and/or reproduce at intermediate points along their migratory path?

In what migrants, other than A. junius, is overwintering in larval diapause an alternative to migration? Do these have a summer generation in regions north of their overwintering range?

What environmental cues cause individuals of such species to switch between the diapausing and migratory strategies?
How will larval phenology, especially in temperate zone facultative migrants like A. junius, be affected by global climate change, and what impacts might this have on migration?

Does larval crowding either cue or select for adult migration (Dumont and Hinnekent, 1973)?

Are any migrants, especially ITCZ migrants, desiccation resistant in egg or larval stages (Dumont 1977; Van Damme and Dumont 1999)?

To what extent do the patterns of migration inferred above, based largely on the presence or absence of facultative larval diapause, represent ends of a continuum as opposed to distinct categories?

Are patterns of migration in the Southern Hemisphere consistent with those of the Northern Hemisphere [e.g., Rhionaeschna bonariensis in Argentina (Jaramillo 1993); Anaxgibbosulus, A. guttatus, A. (Hemianax) papuensis in Australia (Corbet 1999)].

Does the influx of immigrants prevent selective equilibrium in facultative migrants? In ITCZ migrants?

Do migrant Odonata generally have nearly panmictic populations, as in Anax junius in eastern North America, or does some isolation, and therefore spatial structure in genetic characteristics, exist within or among populations [e.g., P. flavescens in North and South America vs. India and Africa; Anax imperator in Europe (mostly nonmigratory) vs. Africa (mostly migratory)]?

This list of questions is by no means exhaustive, but it does sum up a number of serious remaining gaps in knowledge. Clearly this subject is far from exhausted and may continue to provide new insights into the adaptive phenomenon of insect migration in general, potential effects of migration on ecosystems that produce and receive large numbers of migrants, effects of climate change on long-distance dispersal, and positive or negative effects of anthopogenic disturbance on migrant species. None of the dragonfly species known to be migrants in North America is currently threatened, but identifying the habitats on which migrating dragonflies rely for their transcontinental flights may help us better protect these important systems. Threats to wetland habitats, including the effects of global climate disruption, could alter environmental cues for migration, affect larval development and adult emergence times, disrupt migratory corridors, or render overwintering habitat unsuitable (Mazzacano 2011).

Acknowledgments I wish to express my appreciation to Drs. Scott Black and Celeste Mazzacano of the Xerces Society for their inspiration and encouragement to write this review, and to Drs. John Matthews and Dennis Paulson for many very helpful discussions and for commenting on an earlier draft of the paper and to Dr. Michael Samways for a very helpful review. I also thank the many other colleagues, who have shared their knowledge of and enthusiasm for the phenomenon of Odonata migration over the years,. 
Open Access This article is distributed under the terms of the Creative Commons Attribution License which permits any use, distribution, and reproduction in any medium, provided the original author(s) and the source are credited.

\section{References}

Abtew W, Huebner RS, Ciuca V (2006) Hydrology of the South Florida environment. 2006 South Florida Environmental Report, vol I, Chap. 5, pp 5-1-5-85. http://my.sfwmd.gov/portal/page/ portal/pg_grp_sfwmd_sfer/portlet_prevreport/2006_sfer/volume1/ chapters/v1_ch_5.pdf. Accessed 15 April 2012

Anderson RC (2009) Do dragonflies migrate across the western Indian Ocean? J Trop Ecol 25:347-358

Anholt BR, Marden J, Jenkins D (1991) Patterns of mass gain and sexual dimorphism in adult dragon-flies. Can J Zool 69: $1156-1163$

Arnaud PH (1972) Mass movement of Sympetrum corruotum [sic] (Hagen) (Odonata: Libellulidae) in central California. Pan-Pac Entomol 48:75-76

Bagg AM (1958) Fall emigration of the dragonfly, Anax junius. Maine Field Nat 14:2-13

Bayer R (1997) 19-21 September 1997 directed flights of dragonflies: a preliminary report. http://web.archive.org/web/200712220002 03/http://www.ent.orst.edu/ore_dfly/migrate.htm\#rep, http://www.ent.orst.edu/ore_dfly/migrate.htm\#rep. Accessed 7 June 2011

Boomsma T, Dunkle SW (1996) Odonata of Belize. Odonatologica 25:17-29

Borders B, Shepherd M (2011) Milkweeds: not just for Monarchs. Wings 34(1):14-18

Borror DJ (1953) A migratory flight of dragonflies. Entomol News 64:204-205

Butler T, Peterson JE, Corbel PS (1975) An exceptionally early and informative arrival of adult Anax junius in Ontario (Odonata, Aeshnidae). Can Entomol 107:1253-1254

Calvert PP (1893) Catalogue of the Odonata of the vicinity of Philadelphia with an introduction to the study of this group of insects. Trans Am Entomol Soc 26:272-1523

Catling PM (2004) Anax junius overwintering in eastern Ontario. Ont Odonata 4:9-10

Catling PM, Brownell VR (1998) Migratory concentrations of dragonflies on the north shore of Lake Ontario, and northward extension of migratory species. Argia 10(4):19-22

Chapman JW, Reynolds DR, Mouritsen H, Hill JK, Riley JR, Sivell D, Smith AD, Woiwod IP (2008) Wind selection and drift compensation optimize migratory pathways in a high-flying moth. Curr Biol 18:514-518

Cook C (1991) Editor's comments. Argia 3(4):14

Corbet PS (1979) Pantala flavescens in New Zealand (Anisoptera: Libellulidae). Odonatologica 8:115-121

Corbet PS (1984) Orientation and reproductive condition of migrating dragonflies (Anisoptera). Odonatologica 13:81-88

Corbet PS (1999) Dragonflies: Behavior and ecology of Odonata. Cornell University Press, Ithaca

Corbet PS, Eda S (1969) Odonata in southern Ontario, Canada, in August 1968. Tombo 12:4-11

Crumrine PW (2010) Body size, temperature, and seasonal differences in size structure influence the occurrence of cannibalism in larvae of the migratory dragonfly, Anax junius. Aquat Ecol 44:761-770

Daigle JJ (1991) A late summer collecting trip to Texas. Argia 3(4):8
Davey P (1999) Weather conditions leading to the 1998 Green Darner Anax junius (Drury) influx. Atropos 6:8-11

De Marmels J, Clavijo AJ, Sharpe C (2008) Mass migration of the spot-winged glider (Pantala hymenaea) in Venezuela. Argia 20(2):6

Dijkstra K-DB, Lewington R (2006) Field guide to the dragonflies of Britain and Europe. British Wildlife Publishing, Gillingham

Dingemanse N, Kalkman VJ (2008) Changing temperature regimes have advanced the phenology of Odonata in the Netherlands. Ecol Entomol 33:394-402

Dingle H (1996) Migration: The biology of life on the move. Oxford University Press, Oxford

Dingle H (2006) Animal migration: is there a common migratory syndrome. J Ornithol 147:212-220

Dumont HJ (1977) On migrations of Hemianax ephippiger (Burmeister) and Tramea basalis (P. de Beauvois) in west and north-west Africa in the winter of 1975/1976 (Anisoptera: Aeshnidae, Libelludiae). Odonatologica 6:13-17

Dumont HJ (1988) Hemianax ephippiger (Burmeister) in the northern Algerian Sahara in winter (Anisoptera: Aeshnidae). Notulae Odonatologicae 3:20-22

Dumont HJ, Desmet K (1990) Trans-Sahara and trans-Mediterranean migratory activity of Hemianax ephippiger (Burmeister) in 1988 and 1989. (Anisoptera: Aeshnidae). Odonatologica 19:181-185

Dumont HJ, Hinnekint BON (1973) Mass migration in dragonflies, especially Libellula quadrimaculata $\mathrm{L}$ : a review, a new ecological approach and a new hypothesis. Odonatologjca 2:1-20

Dunkle S (1976) Notes on the Anisoptera fauna near Mazatlan, Mexico, including dry to wet season changes. Odonatologica 5:207-212

Dyatlova ES, Kalkman VJ (2008) Massive migration of Aeshna mixta and Sympetrum meridionale in the Ukrainian Danube delta (Odonata-Anisoptera: Aeschnidae, Libellulidae). Entomol Bericht 68:188-190

Feng H-Q, Wu K-M, Ni Y-X, Cheng D-F, Guo Y-Y (2006) Nocturnal migration of dragonflies over the Bohai Sea in northern China. Ecol Entomol 31:511-520

Fraser FC (1936) Odonata. The Fauna of British India including Ceylon and Burma, vol III. Taylor and Francis, London

Freeland JR, May M, Lodge R, Conrad KF (2003) Genetic diversity and widespread haplotypes in a migratory dragonfly, the common green darner Anax junius. Ecol Entomol 28:413-421

Glotzhober RC (1991) Ohio dragonfly survey produces interesting observations: "stinging dragonflies" and migrating swarms. Argia 3(4):13-14

Goswami BN, Venugopal V, Sengupta D, Madhusoodanan MS, Xavier PK (2006) Increasing trend of extreme rain events over India in a warming environment. Science 314:1442-1445

Hagen H (1861) Über Insektenzuge. Stett Entomol Zeit 22:73-83

Haritonov A, Popova O (2011) Spatial displacement of Odonata in South West Siberia. Int J Odonatol 14:1-10

Hassall C, Thompson DJ, French GC, Harvey IF (2007) Historical changes in phenology of British Odonata are related to climate. Global Change Biol 13:933-941

Hickling R, Roy DB, Hill JK, Thomas CD (2005) A northward shift of range margins in British Odonata. Global Change Biol 11:502-506

Highfield R (2006) Tag uncovers long-distance secret of Dave the Dragonfly. Telegraph, 10 May 2006. http://www.telegraph.co. uk/news/uknews/1517932/Tag-uncovers-long-distance-secret-ofDave-the-Dragonfly.html. Accessed 22 June 2011

Hobson KA, Sotol DX, Paulson DR, Wassenaar LI, Matthews JH (2012) A dragonfly $\left({ }^{2} \mathrm{H}:{ }^{1} \mathrm{H}\right)$ isoscape for North America: a new tool for determining natal origins of migratory aquatic emergent insects. Meth Ecol Evol 3:766-772 
Jaramillo AP (1993) Wintering Swainson's hawks in Argentina: food and age segregation. Condor 95:475-479

Johnson CG (1969) Migration and dispersal of insects by flight. Methuen, London

Kennedy JS (1961) A turning point in the study of insect migration. Nature 189:785-791

Kennedy JS (1985) Migration, behavioural and ecological. In: Rankin MA (ed.) Migration: Mechanisms and adaptive significance. Contrib Marine Sci 27(supplement):5-26

Kime JB (1974) Ecological relationships among three species of aeshnid dragonfly larvae (Odonata: Aeshnidae). Dissertation, University of Washington

Koehler CS (1965) Migration of the dragonfly, Tarnetrum corruptum (Hagen). Pan-Pac Entomol 41:66-67

Kumar A (1984) On the life history of Pantala flavescens (Fabricius) (Libellulidae: Odonata). Ann Entomol 2:43-50

Larsen JB (1987) A migration of Pantala flavescens (Fabr.) in South India (Anisoptera: Libellulidae). Notulae Odonatologicae 2:154

Macy RW (1949) On a migration of Tarnetrum corruptum (Hagen) (Odonata) in Western Oregon. Can Entomol 81:50-51

Matthews JH (2004) Report on Anax junius emergence in Caledon, Ontario, in 2003. Ontario Odonata 5:12-14

Matthews JH (2007a) Wetland invertebrates and climate change: what happens when the pond is half-empty? Wings 30(2):5-10

Matthews JH (2007b) Anthropogenic climate change impacts on ponds: A thermal mass perspective. In: Ott $\mathbf{J}$ (ed) Odonate conservation: Climate change impacts and monitoring strategies. Pensoft Publishers, Sofia, pp 183-207

Matthews JH (2007c) In Research in motion: patterns of large-scale migration in dragonflies and birds. Dissertation, University of Texas

May ML, Matthews JH (2008) Migration in Odonata: An overview with special focus on Anax junius. In: Córdoba-Aguilar A (ed) Dragonflies, model organisms for ecological and evolutionary research. Oxford University Press, Oxford, pp 63-77

Mazzacano C (2011) Watching the devil's horses pass by. Wings 34(1):24-28

Mitchell FL, Lasswell J (2005) A dazzle of dragonflies. Texas A \& M University Press, College Station

Moore NW (1993) Behaviour of imaginal Pantala flavescens (Fabr.) on Easter Island (Anisoptera: Libellulidae). Odonatologica 22(71):76

Morton ES (1977) Ecology and behavior of some Panamanian Odonata. In: Proceedings of the entomological society, vol 79, Washington, pp 273

Nicoletti FJ (1996) American kestrel and merlin migration correlated with green darner movements at Hawk ridge. Loon 68:216-221

Nisbet ITC (1960) Notes on the migration of dragonflies in southern Ontario. Can Field Nat 74:150-153

Oberhauser KD, Cotter D, Davis D, Decarie R, Behnumea AE, Galindo-Leal C, Gallina Tessaro MP, Howard E, Lauriault J, Macziewski W, Malcolm S, Martinez F, Gonzalez JM, McRae M, Nernberg D, Baruch IP, Ramirez I, Reyes JJ, Wilson A (2008) North American Monarch Conservation Plan. Commission for Environmental Cooperation, Quebec City. http://www. cec.org/Storage/62/5431_Monarch_en.pdf. Accessed 29 June 2011

Odonata Central (2012a) Checklists: choose a region: North America. http://www.odonatacentral.org/index.php/ChecklistAction.show Checklist/location_id/7. Accessed 8 April 2012

Odonata Central (2012b) Distribution map of Sympetrum corruptum. http://www.odonatacentral.org/index.php/MapAction.windowed. Accessed 12 April 2012

Opler PA (1971) Mass movement of Tarnetrum corruptum (Odonata: Libellulidae). Pan-Pac Entomol 47:223

Orr RL (1996) The Odonata of Patuxent wildlife research center and vicinity. Bull Am Odonatol 4:37-67
Osburn RC (1916) A migratory flight of dragonflies. J N Y Entomol Soc 24:90-92

Ott $\mathbf{J}$ (2001) Expansion of Mediterranean Odonata in Europe and Germany-consequences of climate change. In: Walther G-R, Burga CA, Edwards PJ (eds) Fingerprints of climate changeadapted behaviour and shifted species ranges. Kluwer, New York, pp 89-109

Paulson DR (1984) Odonata from the Yucatan Peninsula, Mexico. Notulae Odonatologicae 2:33-38

Paulson DR (1996) The dragonflies of Washington. Bull Am Odonatol 4:7-91

Paulson DR (1999a) Dragonflies (Odonata: Anisoptera) of southern Florida. Occ Pap Slater Museum, No. 57

Paulson DR (1999b) Notes on Mexican odonates. The Odonata-1 Archives. https://mailweb.ups.edu/pipermail/odonata-1/1999October/001280.html, Accessed 23 June 2011

Paulson DR (2002) Odonata records from Nayarit and Sinaloa, Mexico, with comments on natural history and biogeography. Odonatologica 31:359-370

Paulson DW, Dunkle SW (2012) A checklist of North American Odonata including English name, etymology, type locality, and distribution. Odonata Central. http://www.odonatacentral.org/ docs/NA_Odonata_Checklist_2012.pdf. Accessed 12 April 2012

Pellow K (1999) An influx of Green Darner Anax junius (Drury) into Cornwall and the Isles of Scilly-the first European records. Atropos 6:3-8

Pilgrim E, van Dohlen C (2012) Phylogeny of the dragonfly genus Sympetrum (Odonata: Libellulidae). Org Divers Evol 10:281-295

Pinhey E (1979) Examples of anisopteran swarms (Odonata). Arnoldia Bulawayo 8(37):1-2

Root FM (1912) Dragon flies collected at point Pelee and Pelee Island, Ontario, in the summers of 1910 and 1911. Can Entomol 44:208-209

Russell RW, Wilson JW (1997) Radar-observed "fine lines" in the optically clear boundary layer: reflectivity contributions from aerial plankton and its predators. Boundary-Layer Meteorol $82: 235-262$

Russell RW, May ML, Soltesz KL, Fitzpatrick JW (1998) Massive swarm migrations of dragonflies (Odonata) in eastern North America. Am Midl Nat 140:325-342

Samways MJ (1998) Establishment of resident Odonata populations on the formerly waterless Cousine Island, Seychelles: an Island Biogeography Theory (IBT) perspective. Odonatologica 27:253-258

Samways MJ, Caldwell P (1989) Flight behaviour and mass feeding swarms of Pantala flavescens (Fabricus) (Odonata: Anisoptera: Libellulidae). J Entomol Soc South Afr 52:326-327

Samways MJ, Osborn R (1998) Divergence in a transoceanic circumtropical dragonfly on a remote island. J Biogeogr 25: 935-946

Sang A, Teder T (2011) Dragonflies cause spatial and temporal heterogeneity in habitat quality for butterflies. Insect Conserv Diver 4:257-264

Seager R, Tzanova A, Nakamura J (2009) Drought in the Southeastern United States: causes, variability over the last millennium, and the potential for future hydroclimate change. J Climate 22: $5021-5044$

Shannon HJ (1916) Insect migrations as related to those of birds. Scien Mon 3:227-240

Shannon HJ (1935) The book of the seashore. The life experiences of a naturalist on the beach. Doubleday, Doran and Company, Garden City

Soltesz K (1992) An invasion of Tramea calverti on the Northeast coast. Argia 4(3):9-10

Soltesz K, Barber B, Carpenter G (1995) A spring dragonfly migration in the Northeast. Argia 7(3):10-14 
Sones J (1995) Dragonfly flights on Cape Cod, Massachusetts. Argia $7(2): 8-10$

Southwood TRE (1962) Migration of terrestrial arthropods in relation to habitat. Biol Rev 37:171-214

Sprandel GL (2001) Fall dragonfly (Odonata) and butterfly (Lepidoptera) migration at St. Joseph Peninsula, Gulf County, Florida. Fla Entomol 84:234-238

Srygley RB (2003) Wind drift compensation in migrating dragonflies Pantala (Odonata: Libellulidae). J Ins Behav 16:217-232

Srygley RB, Dudley R (2008) Optimal strategies for insects migrating in the flight boundary layer: mechanisms and consequences. Integ Comp Biol 48:119-133

Suhling F, Schenk K, Padeffke T, Martens A (2004) A field study of larval development in a dragonfly assemblage in African desert ponds (Odonata). Hydrobiologia 528:75-85

Taylor LR (1974) Insect migration, flight periodicity and the boundary layer. J Anim Ecol 43:225-238

Trottier R (1966) The emergence and sex ratio of Anax junius Drury (Odonata: Aeshnidae) in Canada. Can Entomol 98:795-798

Trottier R (1971) Effect of temperature on the life-cycle of Anax junius (Odonata: Aeshnidae) in Canada. Can Entomol 103: $1671-1683$

Van Damme K, Dumont H (1999) A drought-resistant larva of Pantala flavescens (Fabricius, 1798) (Odonata: Libellulidae) in the Lençóis Maranhenses, NE-Brazil. Int J Odonatol 2:69-76
Walker EM (1958) The Odonata of Canada and Alaska. The Anisoptera-Four Families, vol II. University of Toronto Press, Toronto

Walter S (1996) Fort Tilden dragonfly migration watch. Argia 8(1): $8-13$

White HB, Raff RA (1970) Early spring emergence of Anax junius (Odonata: Aeshnidae) in central Pennsylvania. Can Entomol 102:498-499

Wiedner DS, Kerlinger P, Sibley DA, Holt P, Hough J, Crossley R (1992) Visible morning flight of neotropical landbird migrants at Cape May, New Jersey. Auk 109:500-510

Wikelski M, Moskowitz D, Adelman JS, Cochran J, Wilcove DS, May ML (2006) Simple rules guide dragonfly migration. Biol Lett 2:325-329

Williams CB (1958) Insect migration. Collins, London

Williams AP, Funk C (2011) A westward extension of the warm pool leads to a westward extension of the walker circulation, drying eastern Africa. Clim Dyn 37:2417-2435

Wissinger SA (1988) Life history and size structure of larval dragonfly populations. J N Amer Benthol Soc 7:13-28

Wright M (1945) Dragonflies predaceous on the stablefly. Fla Entomol 28:11-13

Young AM (1967) The flying season and emergence period of Anax junius in Illinois (Odonata: Aeshnidae). Can Entomol 99: 886-890 